\title{
The Relationship between Globalization-Public Expenditure on the Basis of the Compensation and Efficiency Hypotheses
}

\author{
Yahya Can DURA*, Selin YALÇINTAŞ**
}

\begin{abstract}
The study, which deals with the changes created by the globalization indicators on the public sector, is shaped on the basis of the compensation and efficiency hypothesis. In this context, it has been investigated how the government size is affected due to the fact that the effects of globalization are felt more with the shift of transition countries from centrally planned economy to free market economy. According to panel OLS and causality test results, increases in economic freedom index, one of the globalization indicators, decrease public consumption expenditure. In this context, the efficiency hypothesis is valid for Albania, Bulgaria, Czechia, Estonia, Romania and Slovakia for the period 1995-2019.
\end{abstract}

Keywords: Globalization, Compensation Hypothesis, Efficiency Hypothesis, Panel OLS, Dumitrescu Hurlin Panel Causality Test

JEL Classification: E62, F02

\section{Telafi ve Etkinlik Hipotezleri Temelinde Küreselleşme ve Kamu Harcamaları İlişkisi}

\section{ÖZ}

Küreselleşme göstergelerinin kamu kesimi üzerinde yarattığı değişimlerin ele alındığı çalışma, telafi ve etkinlik hipotezi temelinde şekillendirilmiștir. Bu kapsamda geçiş ülkelerinin merkezi planlı ekonomiden serbest piyasa ekonomisine yönelmeleriyle birlikte küreselleşme etkilerinin daha fazla hissedilmesi nedeniyle devlet boyutunun ne şekilde etkilendiği araştırılmıştır. Panel OLS ve nedensellik testi sonuçlarına göre küreselleşme göstergelerinden biri olan ekonomik özgürlük indeksindeki artışlar kamu tüketim harcamalarını azaltmaktadır. Bu bağlamda 1995-2019 dönemi itibariyle Arnavutluk, Bulgaristan, Çekya, Estonya, Romanya ve Slovakya için Etkinlik Hipotezi geçerlidir.

Anahtar Kelimeler: Küreselleşme, Telafi Hipotezi, Etkinlik Hipotezi, Panel OLS, Dumitrescu Hurlin Panel Nedensellik Testi

JEL Sinıflandırması: E62, F02

Geliş Tarihi / Received: 22.08.2021 Kabul Tarihi / Accepted: 23.11.2021

Doi: 10.17541/optimum.985925

\footnotetext{
* Dr. Öğr. Üyesi, İstanbul Gelişim Üniversitesi, İktisadi İdari ve Sosyal Bilimler Fakültesi, Uluslararası Ticaret ve Finansman Bölümü, ycdura@gelisim.edu.tr, ORCID: 0000-0002-5662-7748

** Arş. Gör., İstanbul Gelişim Üniversitesi, İktisadi İdari ve Sosyal Bilimler Fakültesi, Uluslararası Ticaret ve Finansman Bölümü (İngilizce), syalcintas@ gelisim.edu.tr, ORCID: 0000-0003-2431-4875
} 


\section{INTRODUCTION}

Globalization is a multidimensional concept that has different explanations in terms of economic, political, social, cultural and technological issues. In addition to the lack of a common definition of globalization, there is no consensus on its consequences. In accordance with the scope of the study, the economic dimension of globalization is discussed. In this context, we can define globalization in its most general form as the construction of a dynamic structure based on interdependence in which economic borders disappear and national economies integrate with each other. Economically, it is possible to monitor globalization in terms of trade, production and finance.

Although globalization discourses were conceptually shaped in the recent past, the beginning and development of the process dates back many years. While the years between the Industrial Revolution and the First World War were defined as the golden age of globalization, the globalization process was reversed in the period between the First World War and the Second World War. International economic institutions such as the IMF and the World Bank entered the global stage with the adoption of the Bretton Woods system in 1944. The foundation of the globalization of trade was laid with the creation of the GATT in 1947. In addition to the globalization of trade, multinational companies that support the globalization of production have increased their activities and created a global value chain (Wallerstein, 2012). On the other hand, as a result of the adoption of Keynesian fiscal policies in the post-war period, when globalization started to rise again, public expenditure increased, and the development of social welfare states came into question.

The Keynesian fiscal approach, which functioned as the dominant policy, was abandoned due to the fact that it could not produce a solution to the high inflation and the increase in unemployment after the oil crises in the 1970s.

In the 1980s, characterized by the abandonment of Keynesian policies and the rise of neoliberal policies, the goals of increasing the functionality of the dynamic structure of globalization became more important. In this context, the international integration of financial markets has accelerated and the financial globalization process, which is the last link of the economic globalization dimension, has begun. The wave of hyper-globalization, which started in the 1990's and continued increasingly in the 2000's, represents the rapid increase in trade and capital flows (Subramanian and Kessler, 2013).

The fact that the globalization process has evolved into hyper-globalization in recent years has deepened the debates on the role and function of the government. In other words, the answer sought for the question of whether or how globalization has an impact on the government size remains relevant.

Countries that have switched from a centrally planned economy to a free market economy after the dissolution of the USSR are called "transition countries". In 1991, economic reforms were announced by these countries and started to be implemented (Güler, 2012). From this period, with the start of the transition process and the acceleration of globalization, the adaptation of countries to the free-market economy and the analyzing of the role of the public sector have gained importance. Analyzing the relationship between globalization and the government size in terms of economic conditions of the transition countries allows an analysis in a broader perspective. For this reason, it is thought that the findings obtained in the present study will contribute to the evaluation of countries with similar economies.

There are various studies testing the compensation and efficiency hypothesis in the literature, but the number of studies conducted in the context of transition economies is quite limited. Accordingly, our study is one of the rare studies that deals with the relationship between public expenditure and globalization indicators in transition economies. It differs from other 
studies in terms of the period analyzed in the transition countries and the models used in the analysis. In addition, while testing the compensation and efficiency hypotheses in the current study, trade and economic freedom indicators were included in the variables defining globalization, unlike other studies.

The theoretical framework and literature review on the compensation and efficiency hypotheses are given in the second and third chapters. The fourth chapter includes the data set and analysis of the econometric models used in the study. The last part of the study consists of the conclusion and evaluation part.

\section{THE COMPENSATION AND EFFICIENCY HYPOTHESES}

The approach seeing the market and the government as substitutes accepts that the government intervention is against the functioning of the market. There is a common perception that the international integration of markets reduces the effectiveness of the government activities. Contrary to this view, there is also a view that argues that there may be a complementary relationship between the market and the government. It is argued that the scope of the government expands more in economies that are more integrated with global markets, in other words, the government size is larger in more open economies (Rodrik, 1998). Two different hypotheses have been developed in response to the question of how globalization affects the government size within the framework of these views. The theoretical foundations of the relationship have been established within the scope of the compensation and efficiency hypothesis.

According to the compensation hypothesis, globalization increases the government size by triggering the increase in public expenditure. The reasons for the decision to increase public expenditure in response to globalization in economies were first discussed by Cameron (1978) and later by Rodrik (1998). Increasing the interdependence as a result of the integration of economies into the global system brings some risks (Rodrik, 1998; Altay and Aksu, 2013). The expectation that the expanding scope of the market with globalization will cause an increase in income inequality, economic insecurity and external risks, constitute the factors that increase public expenditure. The demand for the compensation for the losses experienced due to globalization is growing (Sener, Bayrakdar and Hac1oğlu, 2015; Dreher, Jan-Egbert and Heinrich, 2008). The social insurance demand of the voters explains a large part of this relationship. The more vulnerable the workers are to the uncertainty of the external economies and international economic fluctuations, the more likely they are to claim benefits such as unemployment insurance and social security. Meeting this demand helps ordinary workers to face the negative circumstances and risks inherent in economic globalization. In this context, the welfare state acts to compensate for the risks brought by globalization.

According to the Heckscher-Ohlin model, the expansion of trade decreases the demand for the scarce factor of production and increases the demand for the abundant factor of production. The globalization of trade can be against the scarce production factor and trigger income inequality. On the other hand, the multinationalization of production with globalization can play a role in reducing income inequality by increasing investments and employment. However, the probability of international capital leaving the domestic country significantly increases economic insecurity. After the globalization of production and trade, the global identity of finance can multiply both income inequality and economic insecurity. With the integration of financial markets, financial institutions are growing and capturing the great majority of the benefits compared to other sectors. In addition, the volatility of the market is increasing as a result of financial globalization. Increasing volatility in the markets also brings about economic insecurity. According to the compensation hypothesis, the demand for 
preventing the inequality and insecurity produced by globalization increases. These risks may lead to protectionist reactions, but the introduction of the compensation mechanism through the efforts of welfare state can increase support for globalization (Garrett and Mitchell, 2001).

The aforementioned factors such as income inequality, economic insecurity and market volatility constitute the arguments of the compensation hypothesis. Individuals who suffer losses due to these risks or who have a high potential for loss in the future demand compensation from the government. In this context, the compensation hypothesis is examined by considering the demand side (Altay and Aksu, 2013). Governments are trying to achieve the goal of providing stability by expanding the expenditure in order to protect the factors such as labor, which has lower mobility compared to mobile production factors such as capital, from the negative effects of globalization (Leibrecht, Klien and Onaran, 2011).

The efficiency hypothesis is shaped on the basis of the liberal view's understanding of efficiency. Public expenditure is seen as a factor reducing efficiency, and it is claimed that globalization will put pressure on this factor. The effect of public expenditure on reducing international competitiveness by creating inefficiency is underlined. Public expenditure is financed through taxes or borrowing. Taxes cause a decrease in personal assets and affect investment decisions negatively. Borrowing, on the other hand, leads to an increase in real interest rates and a decrease in investments by increasing the real exchange rate. The appreciation of the real exchange rate may have a reducing effect on the competitiveness of domestic producers (Garrett and Mitchell, 2001).

Capital owners are putting pressure on markets for the purpose of reducing government intervention in order to increase their international competitiveness (Borghi, 2008). While the compensation hypothesis deals with the political decision-making mechanism from the demand side, the efficiency hypothesis explains it from the supply side (Altay and Aksu, 2013). As a result, the efficiency hypothesis argues that there is a negative relationship between globalization and public expenditure.

\section{LITERATURE REVIEW}

Due to the effects of globalization on many economic variables, there is a wide literature on the subject. The issue of examining the role of globalization, which has increased in recent years, in the transformation of the economic structures of countries, maintains its importance. The relationship between globalization and government size, which is discussed in two different perspectives, has been tested by various empirical studies.

In the studies that obtained findings supporting the compensation hypothesis, a positive relationship is found between public revenue or public expenditure and trade openness and capital openness indicators that represent globalization dynamics (Cameron, 1978; Rodrik, 1998; Shahbaz, Rehman and Amir, 2010; Taşar, 2016; Sarı and Hotunluoğlu, 2018). On the other hand, studies confirming the validity of the efficiency hypothesis with the findings of a negative relationship between the variables, suggest that globalization and government size have a limiting effect on each other (Balle and Vaidya, 2002; Abizadeh, 2005; Liberati, 2007; Altay and Aksu, 2013; Özek and Bayat, 2020).

As a result of the correlation analysis conducted by Dreher et al. (2008), using the data of 60 countries and OECD countries, no relationship was found between the variables. Similarly, in the study conducted by Sener et al. (2013) for Turkey between the years 1975 and 2013, it was emphasized that there was no causality between government size and trade openness. According to the results of the panel causality test done by Yildiz (2019) with the data of the years between 1995-2015 for 27 OECD countries, a one-way causality relationship was found 
from the globalization index (KOF) to public expenditure. In a study in which MINT countries were analyzed, it was determined that there was a significant relationship between public expenditure and openness, but the same effects were not valid for all countries. According to the findings of the study, it was noted that the compensation hypothesis existed in Mexico and Turkey, and the efficiency hypothesis existed in Indonesia and Nigeria (Tütüncü and Zengin, 2018). Zortuk and Beșer (2014) grouped transition economies according to their democratization levels for the years between 1990 and 2011 and analyzed the dynamics of globalization and government size. In the study, it was concluded that the compensation hypothesis is more likely to exist in transition countries with a strong democratic structure.

Table 1: Summary of Literature Review

\begin{tabular}{|c|c|c|c|c|c|}
\hline Author(s) & Period & Country & Variables & Method & Results \\
\hline $\begin{array}{l}\text { Cameron } \\
(1978)\end{array}$ & 1960-1975 & $\begin{array}{l}18 \quad \text { OECD } \\
\text { countries }\end{array}$ & $\begin{array}{l}\text { Government revenue as a } \\
\text { percentage of GDP/per } \\
\text { capita, annual change in real } \\
\text { GDP, imports/exports as a } \\
\text { percentage of GDP. }\end{array}$ & OLS method & $\begin{array}{l}\text { There is a positive } \\
\text { relationship between } \\
\text { public revenue and trade } \\
\text { openness. }\end{array}$ \\
\hline $\begin{array}{l}\text { Rodrik } \\
\text { (1998) }\end{array}$ & $\begin{array}{l}(1990- \\
1992) \\
(1985- \\
1989)\end{array}$ & $\begin{array}{l}23 \quad \text { OECD } \\
\text { countries }\end{array}$ & $\begin{array}{l}\text { Public expenditure as a } \\
\text { percentage of GDP, total of } \\
\text { exports and imports as a } \\
\text { percentage of GDP }\end{array}$ & $\begin{array}{l}\text { Regression } \\
\text { analysis }\end{array}$ & $\begin{array}{l}\text { There is a positive } \\
\text { correlation between public } \\
\text { expenditure and trade } \\
\text { openness. }\end{array}$ \\
\hline $\begin{array}{l}\text { Balle and } \\
\text { Vaidya } \\
(2002)\end{array}$ & 1987-1994 & USA & $\begin{array}{l}\text { Public expenditure as a } \\
\text { percentage of GDP, trade } \\
\text { share as a percentage of } \\
\text { GDP }\end{array}$ & $\begin{array}{l}\text { Regression } \\
\text { analysis }\end{array}$ & $\begin{array}{l}\text { The efficiency hypothesis } \\
\text { is valid. }\end{array}$ \\
\hline $\begin{array}{l}\text { Abizadeh } \\
(2005)\end{array}$ & $1960-2000$ & $\begin{array}{l}\text { Canada, } \\
\text { USA, Korea, } \\
\text { Singapore, } \\
\text { Egypt and } \\
\text { Uruguay } \\
\end{array}$ & $\begin{array}{l}\text { Public expenditure per } \\
\text { capita, trade openness: } \\
(\mathrm{X}+\mathrm{M}) / \mathrm{GDP}-(\mathrm{X}-\mathrm{M})\end{array}$ & $\begin{array}{l}\text { Time series } \\
\text { analysis }\end{array}$ & $\begin{array}{l}\text { In Canada, Singapore and } \\
\text { Uruguay, the level of trade } \\
\text { openness is increasing, } \\
\text { while the role of the } \\
\text { government is decreasing. }\end{array}$ \\
\hline $\begin{array}{l}\text { Liberati } \\
(2007)\end{array}$ & $1970-2003$ & $\begin{array}{l}18 \text { OECD } \\
\text { countries }\end{array}$ & $\begin{array}{l}\text { Public expenditure, total of } \\
\text { exports and imports as a } \\
\text { percentage of GDP, total of } \\
\text { FDI inflows and outflows, } \\
\text { total of portfolio investment } \\
\text { inflows and outflows }\end{array}$ & $\begin{array}{l}\text { OLS } \\
\text { Dynamic } \\
\text { panel }\end{array}$ & $\begin{array}{l}\text { The efficiency hypothesis } \\
\text { is valid. Capital and trade } \\
\text { openness are negatively } \\
\text { related to government size. }\end{array}$ \\
\hline $\begin{array}{l}\text { Dreher et al. } \\
(2008)\end{array}$ & $\begin{array}{l}1971-2001 \\
1990-2001\end{array}$ & $\begin{array}{l}60 \text { countries } \\
\text { and OECD } \\
\text { countries }\end{array}$ & $\begin{array}{l}\text { Capital expenditures, goods } \\
\text { and services expenditures, } \\
\text { interest payments, } \\
\text { subsidies and other current } \\
\text { transfers, the ratio of total } \\
\text { imports and exports to } \\
\text { GDP, ratio of FDI inflows } \\
\text { and outflows to GDP, } \\
\text { restrictions on capital } \\
\text { account transactions }\end{array}$ & $\begin{array}{l}\text { Correlation } \\
\text { analysis }\end{array}$ & $\begin{array}{l}\text { No relationship was found } \\
\text { between the variables. }\end{array}$ \\
\hline $\begin{array}{l}\text { Shahbaz et } \\
\text { al. }(2010)\end{array}$ & 1971-2006 & Pakistan & $\begin{array}{l}\text { Public expenditure as a } \\
\text { percentage of GDP, imports } \\
\text { and exports as a percentage } \\
\text { of GDP, FDI as a } \\
\text { percentage of GDP, GDP } \\
\text { per capita, unemployment } \\
\text { rate }\end{array}$ & $\begin{array}{l}\text { Cointegration } \\
\text { FMOLS }\end{array}$ & $\begin{array}{l}\text { The compensation } \\
\text { hypothesis is valid. }\end{array}$ \\
\hline
\end{tabular}




\begin{tabular}{|c|c|c|c|c|c|}
\hline $\begin{array}{l}\text { Altay and } \\
\text { Aksu (2013) }\end{array}$ & $1974-2010$ & $\begin{array}{l}15 \quad \text { EU } \\
\text { members and } \\
2 \text { candidate } \\
\text { countries }\end{array}$ & $\begin{array}{l}\text { The share of final public } \\
\text { consumption expenditure } \\
\text { in GDP, } \\
\text { GDP per capita, the } \\
\text { percentage of total imports } \\
\text { and exports in GDP, the } \\
\text { share of net foreign direct } \\
\text { capital inflows in GDP, } \\
\text { population growth rate }\end{array}$ & $\begin{array}{l}\text { Panel data } \\
\text { analysis }\end{array}$ & $\begin{array}{l}\text { The efficiency hypothesis } \\
\text { is valid. There is a negative } \\
\text { relationship between } \\
\text { public expenditure and } \\
\text { foreign trade and FDI. } \\
\text { GDP per capita has a } \\
\text { positive effect on public } \\
\text { expenditure, while the } \\
\text { population growth rate has } \\
\text { a negative effect. }\end{array}$ \\
\hline $\begin{array}{l}\text { Zortuk and } \\
\text { Beşer } \\
(2014)\end{array}$ & 1990-2011 & $\begin{array}{l}24 \text { transition } \\
\text { economies }\end{array}$ & $\begin{array}{l}\text { Ratio of public } \\
\text { consumption expenditure } \\
\text { to GDP, GDP per capita, } \\
\text { ratio of total exports and } \\
\text { imports to GDP, trade } \\
\text { volatility, external risk }\end{array}$ & $\begin{array}{l}\text { Panel data } \\
\text { analysis }\end{array}$ & $\begin{array}{l}\text { Transition countries with } \\
\text { strong democratic } \\
\text { structures tends towards } \\
\text { the Rodrik (compensation) } \\
\text { hypothesis. In countries } \\
\text { with mixed regimes such } \\
\text { as Bosnia and } \\
\text { Herzegovina, Ukraine, } \\
\text { Georgia and Moldova, the } \\
\text { compensation hypothesis is } \\
\text { valid. }\end{array}$ \\
\hline $\begin{array}{l}\text { Sener et al. } \\
(2015)\end{array}$ & $1975-2013$ & Turkey & $\begin{array}{l}\text { Ratio of total imports and } \\
\text { exports to GDP, ratio of } \\
\text { public expenditure to GDP }\end{array}$ & $\begin{array}{l}\text { Unit root } \\
\text { Cointegration } \\
\text { Granger } \\
\text { causality test }\end{array}$ & $\begin{array}{l}\text { A causal relationship } \\
\text { between government size } \\
\text { and trade openness could } \\
\text { not be determined, both } \\
\text { hypotheses are not valid in } \\
\text { the long run in Turkey. }\end{array}$ \\
\hline $\begin{array}{l}\text { Taşar } \\
(2016)\end{array}$ & 1961-2014 & Turkey & $\begin{array}{l}\text { Trade openness rate, public } \\
\text { expenditure, GDP per } \\
\text { capita }\end{array}$ & $\begin{array}{l}\text { Linear time } \\
\text { series } \\
\text { analysis }\end{array}$ & $\begin{array}{l}\text { The compensation } \\
\text { hypothesis is valid. }\end{array}$ \\
\hline $\begin{array}{l}\text { Sar1 and } \\
\text { Hotunluoğlu } \\
(2018)\end{array}$ & 1974-2015 & Turkey & $\begin{array}{l}\text { The share of public } \\
\text { expenditure in GDP, the } \\
\text { share of total imports and } \\
\text { exports in GDP, human } \\
\text { capital, population, GDP } \\
\text { growth rate }\end{array}$ & $\begin{array}{l}\text { ARDL } \\
\text { method }\end{array}$ & $\begin{array}{l}\text { The compensation } \\
\text { hypothesis is valid. }\end{array}$ \\
\hline $\begin{array}{l}\text { Tütüncü and } \\
\text { Zengin } \\
\text { (2018) }\end{array}$ & $1987-2015$ & $\begin{array}{l}\text { MINT } \\
\text { countries }\end{array}$ & $\begin{array}{l}\text { The share of total imports } \\
\text { and exports in GDP, public } \\
\text { expenditure }\end{array}$ & $\begin{array}{l}\text { Panel data } \\
\text { analysis } \\
\text { Cointegration } \\
\text { test }\end{array}$ & $\begin{array}{l}\text { The relationship between } \\
\text { openness and public } \\
\text { expenditure is statistically } \\
\text { significant. } \\
\text { compensation hypothesis is } \\
\text { valid for Mexico and } \\
\text { Turkey, and the efficiency } \\
\text { hypothesis is valid for } \\
\text { Indonesia and Nigeria. }\end{array}$ \\
\hline $\begin{array}{l}\text { Anderson } \\
\text { and Obeng } \\
(2020)\end{array}$ & $\begin{array}{l}1992-2014 \\
1972-2014\end{array}$ & $\begin{array}{l}137 \text { countries } \\
116 \text { countries }\end{array}$ & $\begin{array}{lr}\text { Public } & \text { consumption } \\
\text { expenditure, social welfare } \\
\text { expenditure, } & \text { KOF } \\
\text { globalization } & \text { index, } \\
\text { real GDP per } & \text { capita, } \\
\text { dependency } & \text { ratio, } \\
\text { urbanization, } & \text { total } \\
\text { population, price ratio }\end{array}$ & $\begin{array}{l}\text { Fixed effects } \\
\text { (FE) } \\
\text { Variable } \\
\text { estimation }\end{array}$ & $\begin{array}{l}\text { While globalization of } \\
\text { trade has tended to } \\
\text { increase spending, } \\
\text { financial globalization has } \\
\text { tended to decrease } \\
\text { spending. The positive } \\
\text { impact of globalization of } \\
\text { trade on spending } \\
\text { weakened significantly in } \\
\text { the } 1990 \mathrm{~s} \text { and } 2000 \mathrm{~s} \\
\text { compared to previous } \\
\text { years. }\end{array}$ \\
\hline
\end{tabular}




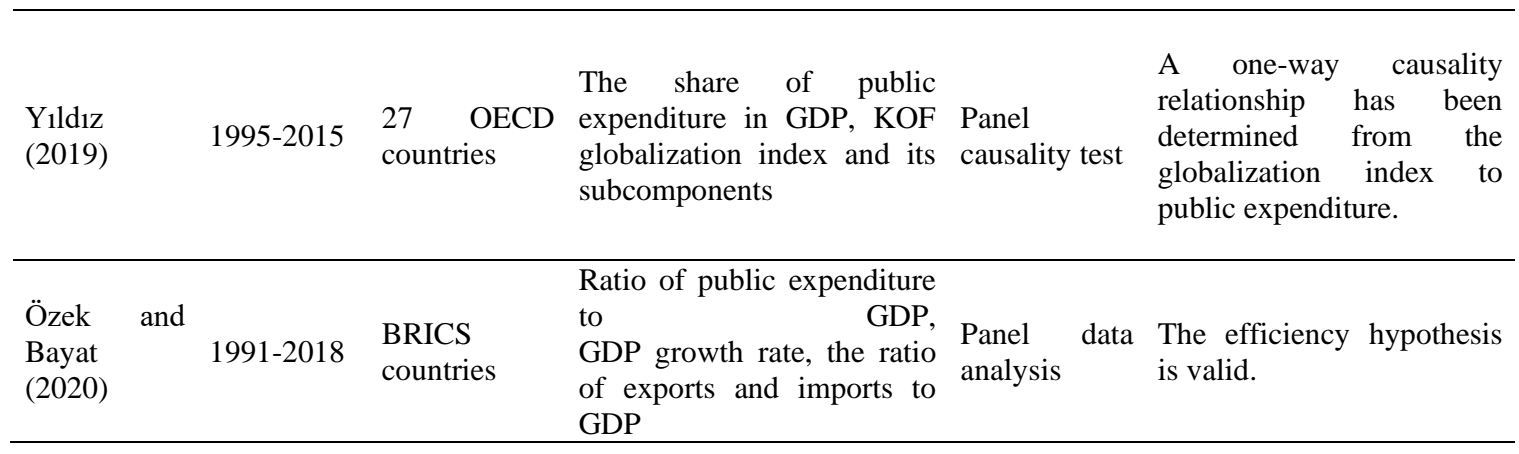

\section{DATA SET AND ANALYSIS}

In this part of the study, the compensation hypothesis and the efficiency hypothesis are tested on a model with the data of the 6 transition countries (Albania, Bulgaria, Czechia, Estonia, Romania and Slovakia) for the period 1995-2019.

\subsection{Model}

Public consumption expenditure was determined as the dependent variable, while the globalization indicators that were the overall score of the Heritage Index of Economic Freedom which is frequently used in the literature, the trade freedom score - one of the sub-parameters of the Heritage Index of Economic Freedom, and the ratio of foreign direct investment to GDP were determined as independent variables while building the model. The effects of the parameters representing globalization can be negative or positive within the framework of this model.

Considering the compensation hypothesis, the assumption of the positive correlation between the globalization process and the indicators representing it, and public expenditures is tested; on the other hand, the efficiency hypothesis tests the assumption of an inverse relationship between the globalization process and the indicators representing it, and public expenditure. The variables in the model, the source of the data set for these variables and the explanation of the data set are presented in Table 2.

Table 2: Variables and Data Set

\begin{tabular}{|c|c|c|c|}
\hline Notation & Variable & Source & Notes \\
\hline \multicolumn{4}{|c|}{ Dependent Variables } \\
\hline $\operatorname{lnKTH}$ & $\begin{array}{l}\text { Logarithm of public } \\
\text { consumption expenditure }\end{array}$ & The World Bank (2021) & In dollars (thousand USD) \\
\hline \multicolumn{4}{|c|}{ Independent Variables } \\
\hline hrt_to & $\begin{array}{l}\text { Heritage trade freedom } \\
\text { score }\end{array}$ & $\begin{array}{l}\text { The Heritage Foundation } \\
(2021)\end{array}$ & $\begin{array}{l}0-100 \\
\text { 100: The best } \\
0: \text { The worst }\end{array}$ \\
\hline ln.hrt_eoos & $\begin{array}{l}\text { The logarithm of the } \\
\text { Heritage economic } \\
\text { freedom overall score }\end{array}$ & $\begin{array}{l}\text { The Heritage Foundation } \\
(2021)\end{array}$ & $\begin{array}{l}0-100 \\
\text { 100: The best } \\
0: \text { The worst }\end{array}$ \\
\hline fdigdp & $\begin{array}{l}\text { Ratio of foreign direct } \\
\text { investment to GDP }\end{array}$ & The World Bank (2021) & $\%$ \\
\hline
\end{tabular}


It was aimed to test the following hypotheses with the econometric analysis process within the scope of the study:

H1: There is a positive relationship between public consumption expenditure, Heritage Economic Freedom overall score and trade freedom sub-score, and the ratio of foreign direct investment to GDP (Testing the Compensation Hypothesis).

$\mathrm{H} 2$ : There is a negative relationship between public consumption expenditure, Heritage Economic Freedom overall score and trade freedom sub-score, and the ratio of foreign direct investment to GDP (Testing the Efficiency Hypothesis).

$\operatorname{lnKTH} H_{\mathrm{i}, \mathrm{t}}=\alpha 0+\beta 1$ hrt_to $\mathrm{i}_{\mathrm{i}, \mathrm{t}}+\beta 2$ ln.hrt_eoos $\mathrm{i}, \mathrm{t}+\beta 2 \mathrm{fdigdp}_{\mathrm{i}, \mathrm{t}}+\varepsilon_{\mathrm{i}, \mathrm{t}}$

$\mathrm{i}=1 \ldots \ldots .6$ ve $\mathrm{t}=1 \ldots \ldots . .25$

\subsection{Method and Results}

Before examining the relationship between the series related to the variables in the model, the cross-sectional dependence forming the panel was tested. The unit root and regression analyses used for the panel data analysis are sensitive to the characteristics of the cross-sectional dependence among the units that make up the panel.

In this context, econometric analysis began with Lagrange Multiplier-LM test which was developed by Breusch-Pagan (1980), the Pesaran (2004) CD test and Adjusted Cross-sectionally Dependence Lagrange Multiplier (LMadj) test developed by Pesaran et al. (2008) to determine the characteristics of cross-sectional dependence of the variables in the established model. The presence of autocorrelation problem was determined by Wooldridge (2002) test. Second generation unit root tests used in panel data analysis were run for the series. CADF (CrossSectionally Augmented Dickey Fuller) and CIPS (CrossSectionally Augmented IPS) unit root test procedures developed by Pesaran (2007) were used because these tests take into account cross-sectional dependence on the one hand, and the structural breaks in the series on the other, and they can be used for situations where the homogeneity assumption cannot be achieved. Then, the Slope Homogeneity Test developed by Pesaran and Yamagata (2008) was performed to determine the homogeneity of the slope coefficients in the cointegration equations.

The panel OLS method was chosen to see the validity of the compensation hypothesis and the efficiency hypothesis in the relevant periods and countries, and to estimate the relationship between the variables in the model established in this context. The stationary of the variables at the level was effective in choosing this method. Dumitrescu and Hurlin (2012) panel causality test was performed to determine the causal relationship between the dependent variable and the independent variables in the model.

Testing of Cross-Section Dependence: Breusch and Pagan (1980) LM and Pesaran et al. (2008) adjusted LM test and Pesaran (2004) CD test were performed to test for the crosssection dependence, and the test results are presented in Table 3. Also, LM, LMadj. and LM-CD test procedures were applied for the whole model and the results are aggregated in Table 4. When evaluated in general, it is seen that the HO hypothesis, which means that there is no crosssection dependence for each variable and for each model, is rejected at the $1 \%$ significance level. In this case, we can accept that there is a cross-sectional dependence in the panel according to the variables included in the analysis and the established model. 
Table 3: Cross-Section Dependence/CD Test Results (For Indicators)

\begin{tabular}{|c|c|c|c|c|c|c|c|c|}
\hline \multirow[b]{2}{*}{ CD Test } & \multicolumn{2}{|c|}{$\operatorname{lnKTH}$} & \multicolumn{2}{|c|}{ to } & \multicolumn{2}{|c|}{ fdigdp } & \multicolumn{2}{|c|}{ eoos } \\
\hline & $\begin{array}{c}\text { Test } \\
\text { Statistics }\end{array}$ & $\mathbf{p}$ & $\begin{array}{c}\text { Test } \\
\text { Statistics }\end{array}$ & $\mathbf{p}$ & $\begin{array}{c}\text { Test } \\
\text { Statistics }\end{array}$ & $\mathbf{p}$ & $\begin{array}{c}\text { Test } \\
\text { Statistics }\end{array}$ & $\mathbf{p}$ \\
\hline $\begin{array}{l}\text { Breusch-Pagan } \\
\text { LM }\end{array}$ & 360.5940 & $0.0000^{*}$ & 218.2675 & $0.0000 *$ & 62.62083 & $0.0000^{*}$ & 178.4261 & $0.0000^{*}$ \\
\hline Pesaran scaled LM & 63.09654 & $0.0000^{*}$ & 37.11140 & $0.0000 *$ & 8.694334 & $0.0000^{*}$ & 29.83739 & $0.0000^{*}$ \\
\hline $\begin{array}{l}\text { Bias-correr. scaled } \\
\text { LM }\end{array}$ & 62.97154 & $0.0000 *$ & 36.98640 & $0.0000 *$ & 8.569334 & $0.0000 *$ & 29.71239 & $0.0000^{*}$ \\
\hline Pesaran CD & 18.98869 & $0.0000 *$ & 14.48625 & $0.0000 *$ & 4.422659 & $0.0000^{*}$ & 12.70500 & $0.0000^{*}$ \\
\hline
\end{tabular}

*\%1 sig. level

Table 4: Cross-Section Dependence LM Test Results (For the Whole Model)

\begin{tabular}{lcc} 
& Test Statistics & p \\
\hline LM & 38.88 & $0.0007^{*}$ \\
LM adj & 10.29 & $0.0000^{*}$ \\
LM CD & 4.043 & $0.0001^{*}$ \\
\hline
\end{tabular}

*\%1 sig. level

Slope Homogeneity Test: Homogeneity and heterogeneity were tested with the Slope Homogeneity Test, and the results are given in Table 5. When the p values are examined, the H0 hypothesis is rejected $(\mathrm{H} 0<0.005)$. That means that the slope coefficients are not homogeneous. The homogeneity test results indicate that the slope coefficients for the variables are heterogeneous.

Table 5: Slope Homogeneity Test Results

\begin{tabular}{ccccccc}
\hline & \multicolumn{2}{c}{ Inkth-to } & \multicolumn{2}{c}{ Inkth- fdigdp } & \multicolumn{2}{c}{ Inkth-eoos } \\
\hline & Delta & p value & Delta & p value & Delta & p value \\
\cline { 2 - 7 } adj. & 4.490 & 0.000 & 4.889 & 0.000 & 2.807 & 0.000 \\
\hline
\end{tabular}

Unit Root Tests: Since the cross-section dependence between the units forming the panel was determined, unit root analysis was carried out with the second-generation panel unit root tests. These tests, unlike first-generation tests, have been developed in order to eliminate the deviation in the finite sample properties that may occur as a result of this relationship, in case of cross-sectional dependence between cross-section units. These tests also perform stationary analysis within the scope of cross-sectional dependence between units.

The parameters used in the study were tested with Pesaran's CADF (Crosssectionally Augmented Dickey Fuller) and CIPS (Cross Sectionally Augmented IPS) tests. Pesaran's CADF assumes that the series that make up the panel data contain an identical component and "it proposes a single factor model defined with heterogeneous factor loads valid in case of crosssectional dependence" (Şak, 2015). 
Unit root test results are presented separately for CADF and CIPS Tests in Tables 6 and 7. According to the results of Pesaran's CADF and CIPS test, stationarity was achieved for all variables used in panel data analysis and it was concluded that there was no unit root.

Table 6: CADF Unit Root Test Results

\begin{tabular}{lcccc}
\multirow{2}{*}{ Variables } & \multicolumn{3}{c}{ Pesaran's CADF test } \\
\cline { 2 - 5 } & Constant & Constant +Trend & Constant & Constant +Trend \\
\cline { 2 - 5 } & $\mathbf{- 3 . 4 2 6 *}^{*}$ & $\mathbf{- 3 . 6 8 6 ^ { * }}$ & ---- & ---- \\
\hline Inkth & $-3.481^{*}$ & $-3.560^{*}$ & --- & ---- \\
hrt_to & $-2.804^{*}$ & $-3.143^{*}$ & ---- & --- \\
fdigdp & $-2.291^{* * *}$ & -2.153 & --- & $-2.912^{* * *}$ \\
ln.hrt_eoos & &
\end{tabular}

“*”, “**” and “***” indicate that the series are stationary at $\% 1, \% 5$ and $\% 10$ sig. levels, respectively.

Table 7: CIPS Unit Root Test Results

\begin{tabular}{lcccc}
\multirow{2}{*}{ Variables } & \multicolumn{4}{c}{ Pesaran's CIPS test } \\
\cline { 2 - 5 } & \multicolumn{3}{c}{ Level } & \multicolumn{2}{c}{ First Difference } \\
\cline { 2 - 5 } & Constant & Constant +Trend & Constant & Constant +Trend \\
\hline lnkth & $\mathbf{- 2 . 8 3 1 ^ { * }}$ & $-\mathbf{2 . 8 7 6 * *}$ & ---- & ---- \\
hrt_to & $-2.981^{*}$ & $-3.068^{* *}$ & ---- & --- \\
fdigdp & $-3.725^{*}$ & $-4.084^{*}$ & ---- & ---- \\
ln.hrt_eoos & $-2.750^{*}$ & $-2.976^{* *}$ & ---- & $\% 1-3.10$ \\
\hline \multirow{2}{*}{ Critical Values } & $\% 1-2.57$ & $\% 1-3.10$ & $\% 1-2.57$ & $\% 5-2.86$ \\
& $\% 5-2.33$ & $\% 5-2.86$ & $\% 5-2.33$ & $\% 10-2.73$ \\
\hline
\end{tabular}

“*”, “**” and “***” indicate $\% 1, \% 5$ and $\% 10$ margin of error, respectively.

Panel OLS Estimation Results: The relationship between public expenditure and the Heritage Economic Freedom overall score, which is selected as a globalization indicator, and trade freedom which is a sub-score of it and the ratio of foreign direct investment to GDP, and the direction of this relationship were estimated by the Panel OLS method within the scope of the established model.

However, before making this estimation, Chow (F) Test, Hausman Test and Lagrange Multiplier (LM) Test were performed to see and choose between random, fixed and pooled effects. According to the test results, it was determined that the optimum model was the random effects model. The test results are given in Table 8, and it was decided to apply the random effects model according to the Hausman and Lagrange Multiplier (LM) tests.

Table 8: Chow (F), Hausman and Lagrange Multiplier (LM) Test Results

\begin{tabular}{lcc}
\cline { 2 - 3 } & p value & Hypothesis Accept-Reject \\
\hline Hausman Test & 0.3358 & $\begin{array}{c}\text { H0 accept, H1 reject } \\
\text { Random } \\
\text { H0 reject, H1 accept } \\
\text { Fixed }\end{array}$ \\
Chow (F) Test & 0.0000 & $\begin{array}{c}\text { H0 reject, H1 accept } \\
\text { Random }\end{array}$ \\
\hline
\end{tabular}


The estimation results of the Panel OLS operated according to the random effects model, are given in Table 9. However, the existence of the autocorrelation problem in the model was tested with the Wooldridge test before, and the existence of autocorrelation was revealed because the probability value was less than 0.05 for the variables subject to the analysis. In order to eliminate the autocorrelation problem, the AR(1) process was applied.

Table 9: Panel OLS Estimation Results

\begin{tabular}{lc}
\hline $\begin{array}{l}\text { Dependent Variable } \\
\text { (nkth) }\end{array}$ & \\
\hline to & -0.884 \\
& $(0.0012)$ \\
fdigdp & -0.821 \\
& $(0.0015)$ \\
lneoos & $-0.003^{*}$ \\
\hline
\end{tabular}

$*, * *$ and $* * *$ indicate statistical sig. at the $\% 10, \% 5$ and $\% 1$ levels, respectively. Values in parentheses represent standard errors.

According to the estimation results reported in Table 9, there is a negative but statistically insignificant relationship between trade freedom, the ratio of foreign direct investment to GDP and public consumption expenditure. However, a negative but statistically significant relationship was found between the overall score of the economic freedom index and public consumption expenditure. Accordingly, the increase in public consumption expenditure for the examined periods and countries, affects the overall scores of the economic freedom index of these countries negatively. In other words, the validity of the efficiency hypothesis has been determined for the period 1995-2019 of 6 transition countries (Albania, Bulgaria, Czechia, Estonia, Romania and Slovakia).

Dumitrescu Hurlin Panel Causality Test: Dumitrescu and Hurlin (2012) panel causality test, which is an extended version of Granger (1969) causality test, has many advantages as a test that can give effective results in both balanced and unbalanced panels, and also allows for cross-sectional dependence (Dumitrescu and Hurlin, 2012).

The stationarity of the series is a prerequisite for the application of this test, and the stationary states of the series were used in the analysis. Test results are presented in Table 10.

Table 10: Dumitrescu and Hurlin Panel Causality Test Results

\begin{tabular}{lcccc}
\hline \multirow{2}{*}{ Variables } & \multicolumn{2}{c}{$\mathbf{k = 1}$} & \multicolumn{2}{c}{$\mathbf{k = 2}$} \\
\cline { 2 - 5 } & Zbar-Stat. & Probability & Zbar-Stat. & Probability \\
\hline lneoos - lnkth & 2.66222 & $0.0078^{*}$ & 0.96757 & 0.3333 \\
to - lnkth & 1.98974 & $0.0466^{* *}$ & -0.57551 & 0.5649 \\
lnkth - to & 9.95894 & $0.0000^{*}$ & 10.2513 & $0.0000^{*}$ \\
lnkth - fdigdp & 1.83829 & $0.0660^{* * *}$ & 3.34100 & $0.0008^{*}$ \\
\hline
\end{tabular}

$*$, ** and *** indicate statistical sig. at the $\% 10, \% 5$ and $\% 1$ levels, respectively. 
Dumitrescu and Hurlin (2012) panel causality test was reported separately for one and two lag lengths. A Granger causality relationship was found from public consumption expenditure to trade freedom and from public consumption expenditure to the ratio of foreign direct investment to GDP in both lag lengths. In addition to these, Granger causality relationship was also reported from the Heritage Index of Economic Freedom overall score to public consumption expenditure and from trade freedom to public consumption expenditure, with one lag length.

\section{CONCLUSION}

The study, which deals with the changes created by the globalization indicators on the public sector, is shaped on the basis of the compensation and efficiency hypothesis. In this context, it has been investigated how the government size is affected due to the fact that the effects of globalization are felt more with the shift of transition countries from centrally planned economy to free market economy.

In the study, the compensation hypothesis and the efficiency hypothesis are tested with the panel data method using data from the period 1995-2019 of 6 transition countries (Albania, Bulgaria, Czechia, Estonia, Romania and Slovakia). Public consumption expenditure was determined as the dependent variable, while the globalization indicators that were the overall score of the Heritage Index of Economic Freedom, the trade freedom score - one of the subparameters of the Heritage Index of Economic Freedom, and the ratio of foreign direct investment to GDP were determined as independent variables while building the model. The characteristics of the cross-section dependence of the variables in the analysis were tested with Breusch and Pagan (1980) LM, Pesaran et al. (2008) adjusted LM test and Pesaran (2004) CD test. As a result of the tests, it was determined that the variables had cross-sectional dependence. On the other hand, according to the results of the Slope Homogenity test, it was determined that the slope coefficients of the variables were heterogeneous.

According to the results of Pesaran's CADF and CIPS unit root test for the variables with cross-sectional dependence, stationarity was achieved for all of the variables, and it was concluded that there was no unit root. After the variables showed stationarity, the Panel OLS method was used to estimate the relationship between the dependent and independent variables. According to the estimation results, there is a negative but statistically insignificant relationship between trade freedom and the ratio of foreign direct investment to GDP, and public consumption expenditure. A negative but statistically significant relationship was found between the overall score of the economic freedom index and public consumption expenditure. Dumitrescu and Hurlin (2012) panel causality test was used to explain the causal relationship between the dependent variable and the independent variables. As a result of the test, which was examined with two lag lengths, a Granger causality relationship was found from public consumption expenditure to trade freedom and from public consumption expenditure to the ratio of foreign direct investment to GDP. As one lag length, Granger causality relationship from Heritage Index of Economic Freedom overall score to public consumption expenditure and from trade freedom to public consumption expenditure was revealed.

According to panel OLS and causality test results, increases in economic freedom index, one of the globalization indicators, decrease public consumption expenditure. In this context, the efficiency hypothesis is valid for Albania, Bulgaria, Czechia, Estonia, Romania and Slovakia for the period 1995-2019. Firms and capital owners in these transition countries play a dominant role in reducing the public expenditure so that production and investment processes are not adversely affected. It is seen that the demand for compensation of the labor factor is not met in the same direction as globalization in the face of the risks that globalization has, especially for 
developing countries. As a result, the incentive to increase the international competitiveness of these countries, which are in the process of transition to a free market economy, triggers decrease in the size of the public sector. As a result of the analysis, it is thought that the findings obtained for the transition countries and the determination of the valid hypothesis will contribute to the development of effective policies by the countries with similar economies.

\section{Declaration of Research and Publication Ethics}

This study has been carried out in accordance with the rules of scientific research and publication ethics.

\section{Authors' Contribution}

The first author's 50\%, the second author's 50\%.

\section{Declaration of Conflict of Interest}

There is no conflict of interest. 


\section{REFERENCES}

Abizadeh, S. (2005). An analysis of government expenditure and trade liberalization. Applied Economics, 37, 18811884.

Altay, A., \& Aysu, A. (2013). Etkinlik ve telafi edici etki hipotezi: seçilmiş ülkeler üzerine ampirik bir inceleme. TiSK Akademi, 8(15), 130-154.

Anderson, E., \& Obeng, S. (2020). Globalisation and government spending: Evidence for the 'hyper-globalisation' of the 1990s and 2000s. The World Economy, 44(5), 1144-1176.

Balle, F., \& Vaidya, A. (2002). A regional analysis of openness and government size. Applied Economics Letters, 9 (5), 289-292.

Bergh, A., \& Karlsson, M. (2010). Government size and growth: Accounting for economic freedom and globalization. Public Choice, 142, 195-213.

Borghi, E. (2008). Trade openness and public expenditure on labor market prices. Departmental Working Papers 2010-21, Department of Economics, Management and Quantitative Methods at Università degli Studi di Milano. 1-25.

Cameron, D. R. (1978). The expansion of the public economy: a comparative analysis. The American Political Science Review, 72(4), 1243-1261.

Dreher, A., Jan-Egbert, S., \& Heinrich, W.U. (2008). The impact of globalization on the composition of government expenditures: Evidence from panel data. Public Choice, 134, 263-292.

Dumitrescu, E. I. \& Hurlin, C. (2012). Testing for Granger noncausality in heterogeneous panels. Economic Modelling, 29(4), 1450-1460.

Garrett, G., \& Mitchell, D. (2001). Globalization, government spending and taxation in the OECD. European Journal of Political Research, 39, 145-177.

Güler, E. (2012). Geçiş ekonomileri ve Yeni Kurumsal İktisat'ın yeniden yükselişi. Doğuş Üniversitesi Dergisi, 13(1), $52-68$.

Leibrecht, M., Klien, M., \& Onaran, O. (2011). Globalization, welfare regimes and social protection expenditures in Western and Eastern European countries. Public Choice, 148(3), 569-594.

Liberati, P. (2007). Trade openness, capital openness and government size. Journal of Public Policy, 27 (2), 215-247.

Özek, Y., \& Bayat, T. (2020). BRICS ülkelerinde etkinlik ve telafi edici etki hipotezlerinin geçerliliğinin test edilmesi. Adlyaman Üniversitesi Sosyal Bilimler Enstitüsü Dergisi, 13(35), 720-741.

Rodrik, D. (1998). Why do more open economies have bigger governments? Journal of Political Economy, 106(5), 997-1032.

Sarı, E., \& Hotunluoğlu, H. (2018). Kamu büyüklüğü ve ticari açıklık bağlamında etkinlik ve telafi hipotezi: Türkiye üzerine ampirik bir analiz. I. Uluslararast Sosyal Bilimlerde Kritik Tartışmalar Kongresi (ICCDSS'18), 728-738.

Sener, S., Bayrakdar, S., \& Hacioğlu, V. (2015). The analysis for the validity of compensation and efficiency hypotheses in Turkey between 1975 and 2013. Procedia-Social and Behavioral Sciences, 195, 624-631.

Shahbaz, M., Rehman, H. U., \& Amir, N. (2010). The impact of trade and financial openness on government size: a case study of Pakistan. Journal of Quality and Technology Management, 6 (1), 105-118.

Subramanian, A., \& Kessler, M. (2013). The hyperglobalization of trade and its future. Working Paper SeriesPeterson Institute for International Economics, 13(6), 1-66.

Şak, N. (2015). Panel Birim Kök Testleri. In S. Güriş (Eds.), Stata ile Panel Veri Modelleri (pp. 203-268). İstanbul: Der Yayınları.

Taşar, İ. (2016). Türkiye'de etkinlik ve telafi edici etki hipotezlerinin geçerliliğinin test edilmesi. Kahramanmaraş Sütçü İmam Üniversitesi İktisadi ve İdari Bilimler Fakültesi Dergisi, 6(2), 15-22.

Tütüncü, A., \& Zengin, H. (2018). Telafi ve etkinlik hipotezlerinin MINT ülkeleri için geçerliliğinin test edilmesi. Anadolu Üniversitesi Sosyal Bilimler Dergisi, 19(1), 81-94.

Wallerstein, I. (2012). Tarihsel Kapitalizm ve Kapitalist Uygarlık (6th Ed.). İstanbul: Metis Yayıncılık.

Yıldız, B. (2019). Küreselleşme ile kamu büyüklüğü arasındaki nedensellik ilişkisi: Oecd ülkeleri örneği. Mali Çözüm Dergisi, 29(155), 81-103.

Zortuk, M., \& Beşer, B. (2014). Dışa açıklık ve demokratik yapının kamu kesimi büyüklüğü üzerindeki etkisi: Rodrik hipotezine geçiş ekonomilerinden kanıt. Ege Akademik Bakış, 14(3), 345-359. 